\title{
Investigation of Triphenylamine (TPA)-Based Metal Complexes and Their Application in Perovskite Solar Cells
}

\author{
Wei Zhang, ${ }^{\dagger}$ Peng Liu, ${ }^{\dagger}$ Azar Sadollahkhani, ${ }^{\dagger}$ Yuanyuan Li, $^{\ddagger}$ Biaobiao Zhang, ${ }^{\S}$ Fuguo Zhang, ${ }^{\S}$ \\ Majid Safdari, ${ }^{\dagger}$ Yan Hao, ${ }^{\|, \perp}$ Yong Hua, ${ }^{*},{ }^{\dagger}, \#$ and Lars Kloo ${ }^{*}, \dagger$
}

${ }^{\dagger}$ Department of Chemistry, Applied Physical Chemistry, ${ }^{\star}$ Department of Fiber and Polymer Technology, Wallenberg Wood Science Center, and ${ }^{\S}$ Department of Chemistry, Organic Chemistry, KTH Royal Institute of Technology, SE-10044 Stockholm, Sweden

"Department of Chemistry-Ångström Laboratory, Physical Chemistry, Uppsala University, SE-75120 Uppsala, Sweden

\section{Supporting Information}

ABSTRACT: Triphenylamine-based metal complexes were designed and synthesized via coordination to $\mathrm{Ni}(\mathrm{II}), \mathrm{Cu}(\mathrm{II})$, and $\mathrm{Zn}$ (II) using their respective acetate salts as the starting materials. The resulting metal complexes exhibit more negative energy levels (vs vacuum) as compared to $2,2^{\prime}, 7,7^{\prime}$-tetrakis( $N, N$-di- $p$-methoxyphenylamine)-9,9' -spirobifluorene (SpiroOMeTAD), high hole extraction efficiency, but low hole mobilities and conductivities. Application of dopants typically used for Spiro-OMeTAD was not successful, indicating a more complicated mechanism of partial oxidation besides the redox potential. However, utilization as hole-transport material was successful, giving a highest efficiency of $11.1 \%$ under AM 1.5G solar illumination.

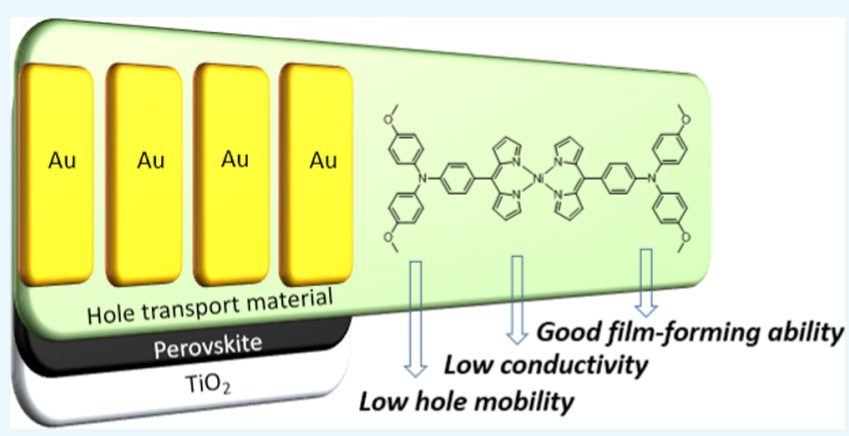

as low as U.S. $\$ 1 / \mathrm{g}$. In comparison, the estimated corresponding Spiro-OMeTAD costs amount to more than U.S. $\$ 33 /$ g. $^{16}$

Metal complexes have shown applications in solar cells for many years. In the beginning, ruthenium(II) complexes were used as photosensitizers, like N3 and N719, ${ }^{17-19}$ in dyesensitized solar cells, being the basis for solar cells with very impressive performance. Later, cobalt ${ }^{20}$ and copper complexes ${ }^{21}$ were used as redox couples to replace the traditional $\mathrm{I}^{-} / \mathrm{I}_{3}{ }^{-}$system due to their tunable redox potentials and longterm stability. In recent years, metal complexes have also been used as hole-transport materials and dopants in perovskite solar cells, such as silver complexes, ${ }^{22}$ porphyrin, ${ }^{23}$ FK209, ${ }^{24}$ and copper complexes. ${ }^{25,26}$ However, the metal complexes reported as hole-transport materials have their limitations and cannot be widely up-scaled. In the silver system, ${ }^{22}$ the compound used is a silver complex cation with $\mathrm{TFSI}^{-}$as an anion offering a significant increase in conductivity, but the strategy was considered as doping. In the copper system, ${ }^{26}$ the structure of the solar cell was sandwich type, and by partial evaporation of the electrolyte, they could generate the so-called "Zombie" cells, which do not correspond to the traditional solid-state solar cells. Hence, we believe that it is meaningful to explore how a traditional metal complex works as a hole-transport material in an all solid-state solar cell.

Received: September 27, 2017

Accepted: November 23, 2017

Published: December 27, 2017 


\begin{tabular}{|c|c|c|c|}
\hline HTMs & Y1 & $\mathrm{Y} 2$ & Y3 \\
\hline LUMO & & & \\
\hline HOMO & & & \\
\hline HOMO-1 & & & \\
\hline
\end{tabular}

Figure 1. Frontier orbitals of Y1, Y2, and Y3.

In this report, we use perovskite as our photosensitizer in all solid-state solar cell. At the same time, we designed and synthesized three different metal complexes with triphenylamine (TPA) derivatives as ligands coordinating to nickel, copper, and zinc, respectively. The aim is to investigate the performance of traditional metal complexes as HTMs and the influence from different metal ion centers on the resulting energy levels, conductivities, hole mobilities, and possible applications of these materials in perovskite solar cells. To the best of our knowledge, this is the first example that studies the effects from different coordinated metals as hole-transport materials in perovskite solar cells. Also, the first example when a nickel and a zinc complex have been investigated in combination with Spiro-OMeTAD.

\section{RESULTS AND DISCUSSION}

The electron distribution of the highest occupied molecular orbitals (HOMOs) with HOMO-1s and the lowest unoccupied molecular orbitals (LUMOs) of the HTM molecules are shown in Figure 1. The HOMOs of these HTM molecules are mainly localized on the ligands. For Y1, the electron clouds are delocalized on both ligands, whereas in $\mathrm{Y} 2$ and $\mathrm{Y} 3$, the electron cloud is localized on predominantly one of the ligands, indicating that transport properties for holes may be different from that of Y1. All of the HOMO-1s have almost the same energy as HOMOs, but with electrons localized on the other ligand. Very little difference in energy between the HOMO and HOMO-1 confirms that the highest occupied MOs essentially are placed on the ligands. The LUMOs are all typically localized on the central metal atoms and adjacent pyrrole rings, and relative poor transport properties for electrons could be implied.

The redox potentials $\left(E_{\mathrm{ox}}\right)$ of $\mathrm{Y} 1, \mathrm{Y} 2, \mathrm{Y} 3$, and Spiro$\mathrm{OMeTAD}$ were determined using cyclic voltammetry $(\mathrm{CV})$ in dichloromethane (DCM) solution (Figure 2a), collected with the corresponding data of energy levels versus vacuum from the calculations in Table 1. The HOMO energy level of $\mathrm{Y} 1$ is -5.43 $\mathrm{eV}$ (vacuum energy scale), which is a bit more negative than those of $\mathrm{Y} 2$ and $\mathrm{Y} 3$, both with an energy level of $-5.38 \mathrm{eV}$, indicating that change in metal cores has only a slight effect on the redox potentials. This is in accordance with the theoretical calculations, which show that the electron density are mainly located in the peripheral parts of the ligands. Thus, it is the redox properties of the ligand that dominate the HOMO
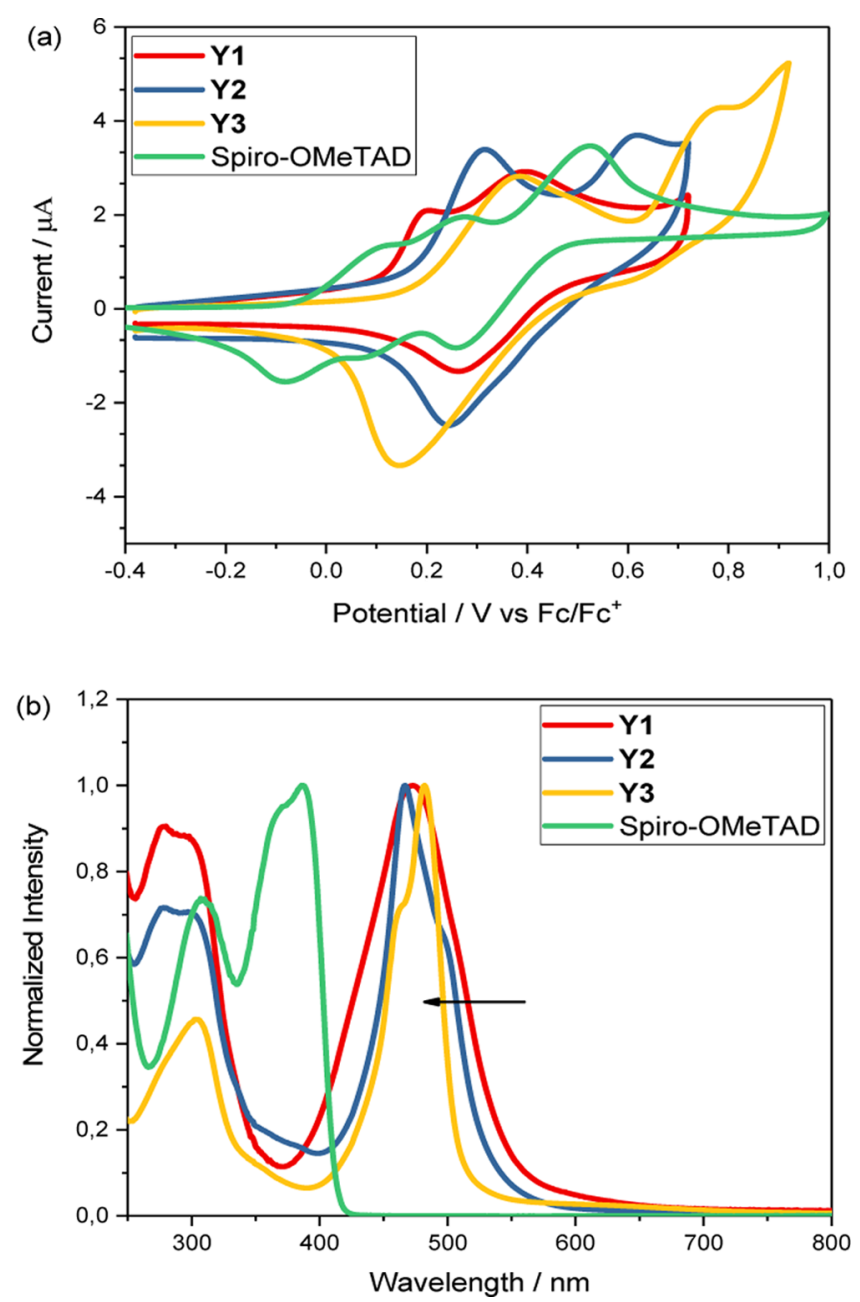

Figure 2. (a) Cyclic voltammograms of the metal complexes in dichloromethane. (b) UV-vis absorption spectra of the metal complexes in chloroform.

energy levels in these complexes and not the metal cores. It is worth mentioning that the redox peaks of Y1, Y2, and Y3 in the $\mathrm{CV}$ are irreversible, probably because of a demetallization process upon oxidation. ${ }^{27,28}$ The redox potential of SpiroOMeTAD was determined to be $-5.12 \mathrm{eV}$ under the same condition, this is in good agreement with the previous report. ${ }^{29}$ 
Table 1. Summary of the Energies of the Experimentally Obtained HOMOs, $E_{0-0}$, and LUMOs, Together with Calculated Energy Levels of the HOMOs and LUMOs ${ }^{a}$

\begin{tabular}{lcccccc}
\multicolumn{1}{c}{ HTMs } & HOMOs/eV & $E_{0-0} / \mathrm{eV}$ & LUMOs/eV & calcd HOMOs/eV & calcd HOMO-1s/eV & -4.73 \\
Y1 & -5.43 & 2.26 & -3.17 & -4.74 & -1.86 & -4.79 \\
Y2 & -5.38 & 2.34 & -3.04 & -4.72 & -4.73 & -1.91 \\
Y3 & -5.38 & 2.44 & -2.94 & -2.12 &
\end{tabular}

${ }^{a}$ Energy levels are given vs vacuum.

Figure $2 \mathrm{~b}$ shows the UV-vis absorption spectra of the different metal complexes in chloroform solution with normalized intensity. It is obvious that the complexes display similar absorption properties, which show a strong red shift as compared to Spiro-OMeTAD. However, as the metal center is changed from nickel to zinc, the maximum absorption band from $\mathrm{d}-\mathrm{d}$ transition slightly shifts to shorter wavelengths, indicating an increase in the band gap of the corresponding solid material. The low intensity of $\pi-\pi^{*}$ and $n-\pi^{*}$ transition in $\mathrm{Y} 2$ and $\mathrm{Y} 3$ can be noted at shorter wavelengths. ${ }^{30}$ The decrease or disappearance of the peak in Y3 due to $n-\pi^{*}$ transition confirms the coordination through $\mathrm{N}$ atom in the pyrrole ring. The $\pi-\pi^{*}$ transition with a shoulder at $299 \mathrm{~nm}$, as well as a new peak at $277 \mathrm{~nm}$, in Y1 and Y2 is caused by the complex formation. The band gap and LUMO energy levels, as well as the calculated energy levels of the HOMOs, HOMO-1s, and LUMOs, are listed in Table 1.

According to the HOMO energy levels in Table 1, all of the systems show more negative energy levels than SpiroOMeTAD $(-5.12 \mathrm{eV})$. Even if the three compounds in principle should be able to oxidize Spiro-OMeTAD, no such reactions could be verified. Results are shown in Figure S9. It seems likely that the mechanism of oxidation is more complicated than just depending on the redox potential of $\mathrm{Y} 1, \mathrm{Y} 2$, and $\mathrm{Y} 3$.

The HOMO energy levels are promising with respect to the function as hole-transport materials in PSCs. First, we studied the hole-transfer properties at the perovskite-HTM interface using steady-state photoluminescence (PL) on a device with the structure of fluorine-doped tin oxide (FTO) $/ \mathrm{TiO}_{2} /$ perovskite/HTM. The results are shown in Figure 3. Devices with a naked perovskite film show a high light emission

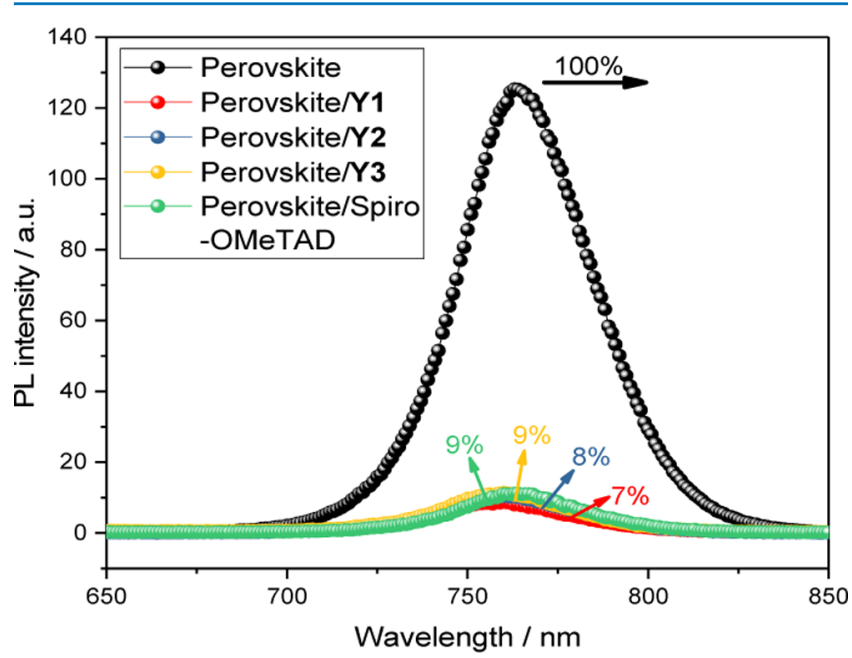

Figure 3. Photoluminescence spectra of perovskite films only, and with Y1, Y2, Y3, or Spiro-OMeTAD as a hole-transport material. intensity due to the radiative recombination between photogenerated electrons and holes. When coating with HTMs, a significant decrease in the emission signals was observed for all of the materials. The PL quenching efficiencies for Y1, Y2, and Y3 are quite high and similar, most likely relating to their comparable HOMO energy levels and the corresponding driving force, indicating highly efficient hole transfer yields between the perovskite films and the HTMs, all above $90 \%$ and at the same level as Spiro-OMeTAD.

The reorganization energy is a key factor affecting the chargetransfer rate. It represents the structural relaxation upon the removal or addition of an electron to the system. Usually, molecular structures showing a smaller reorganization energy will also exhibit faster transfer rates for electrons or holes. As indicated in Table 2, Y2 shows the lowest calculated

Table 2. Reorganization Energy of the Different HTM Molecules As Derived from the Four-Point Method Based on the Adiabatic Potential Energy Surfaces

$\begin{array}{ccccc}\text { HTMs } & \text { Y1 } & \text { Y2 } & \text { Y3 } & \text { Spiro-OMeTAD } \\ \text { reorganization energy }(\mathrm{meV}) & 164 & 149 & 174 & 147\end{array}$

reorganization energy of $149 \mathrm{meV}$, which is comparable to $147 \mathrm{meV}$ for Spiro-OMeTAD. However, compared with Y1 and $\mathrm{Y} 3$, the difference is minor; we should not expect a big difference in the carrier-transport ability among these materials.

Because it is always important to confirm the theoretical calculations from the experiment, we also studied their hole mobilities via the space-charge-limited currents method, ${ }^{31}$ see eq 1. Moreover, conductivities were determined using a twocontact electrical setup following a previously reported procedure, $^{32,33}$ see eq 2 . The results are shown in Figure 4.

$$
J=\frac{9}{8} \mu \varepsilon_{0} \varepsilon_{\mathrm{r}} \frac{V^{2}}{d^{3}}
$$

where $J$ is the current density, $\mu$ is the hole mobility, $\varepsilon_{0}$ is the vacuum permittivity $\left(8.85 \times 10^{-12} \mathrm{~F} \mathrm{~m}^{-1}\right), \varepsilon_{\mathrm{r}}$ is the dielectric constant of the material (normally approximated to 3 for organic semiconductors), $V$ is the applied bias voltage, and $d$ is the film thickness.

$$
\sigma=\frac{L}{R \cdot \mu \cdot d}
$$

where $\sigma$ is the conductivity, $L$ is the channel length (about 2 $\mathrm{mm}$ ), $\mu$ is the channel width (about $10 \mathrm{~mm}$ ), $d$ is the film thickness (around $400 \mathrm{~nm}$ ), $R$ is the film resistance calculated from the gradients of the curves, and defined as the reciprocal of the slope, which is estimated from a least-squares fit of a linear model to the current-voltage data.

As shown in Figure 4a, pristine hole mobilities are quite low. All are around $2 \times 10^{-5} \mathrm{~cm}^{2} \mathrm{~V}^{-1} \mathrm{~s}^{-1}$, as listed in Table 3. The differences are probably within the experimental errors. The 

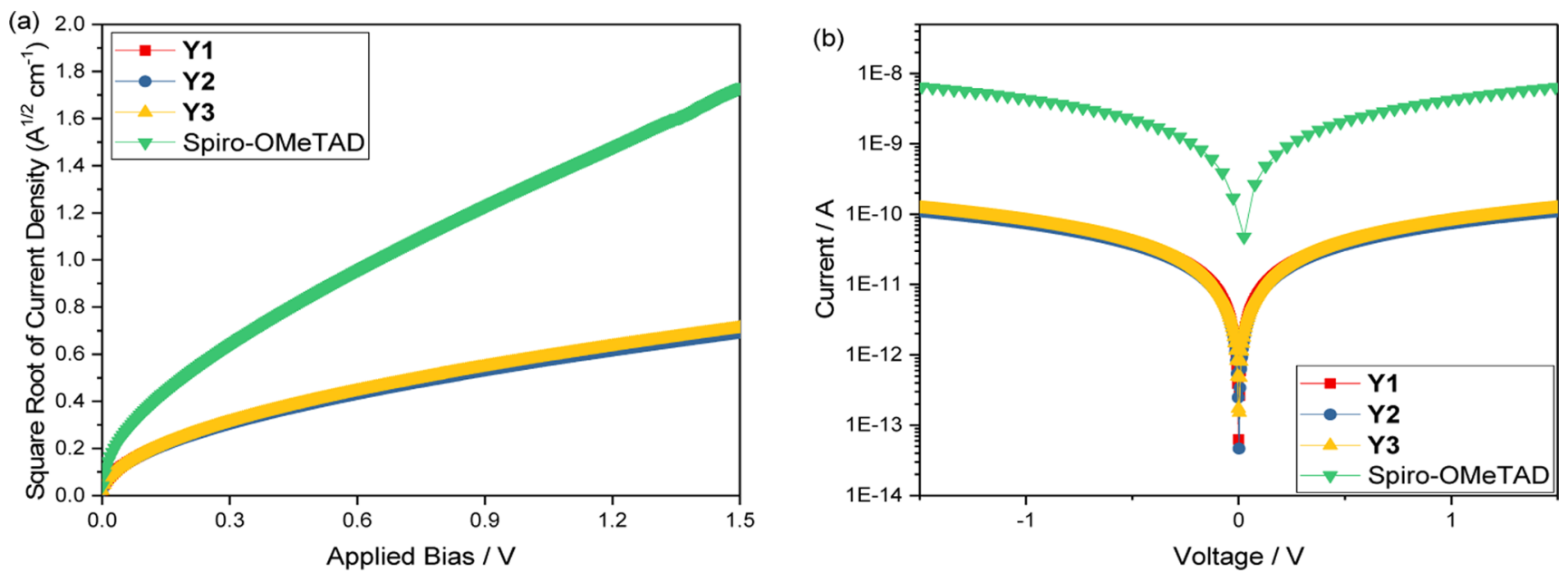

Figure 4. (a) $J-V$ characteristics of thin films in hole-conducting-only devices without doping. (b) Current-voltage characteristics of different HTM films with same amount doping as for the solar cells.

Table 3. Hole Mobilities ${ }^{a}$ and Conductivities ${ }^{b}$ Obtained for Y1, Y2, Y3, and Spiro-OMeTAD

\begin{tabular}{lcc}
\multicolumn{1}{c}{ HTMs } & hole mobility $\left(\mathrm{cm}^{2} \mathrm{~V}^{-1} \mathrm{~s}^{-1}\right)$ & conductivity $\left(\mathrm{S} \mathrm{cm}^{-1}\right)$ \\
Y1 & $1.99 \times 10^{-5}$ & $4.06 \times 10^{-7}$ \\
Y2 & $2.04 \times 10^{-5}$ & $3.66 \times 10^{-7}$ \\
Y3 & $1.88 \times 10^{-5}$ & $4.05 \times 10^{-7}$ \\
Spiro-OMeTAD & $1.69 \times 10^{-4}$ & $2.17 \times 10^{-5}$
\end{tabular}

${ }^{a}$ Hole mobilities were estimated without doping. ${ }^{b}$ Conductivities were determined with the same amount doping as for the solar cells.

mobilities are lower than that of pristine Spiro-OMeTAD, which is about $1.69 \times 10^{-4} \mathrm{~cm}^{2} \mathrm{~V}^{-1} \mathrm{~s}^{-1}$. This is in good agreement with the small differences in calculated reorganization energies. Also, the new materials show lower conductivities as compared to Spiro-OMeTAD. For Y3, the conductivity is $4.05 \times 10^{-7} \mathrm{~S} \mathrm{~cm}^{-1}$. Y1 and Y2 are expected to display better carrier-transport properties. However, they are about the same as for Y3, approximately $4.06 \times 10^{-7}$ and $3.66 \times 10^{-7} \mathrm{~S} \mathrm{~cm}^{-1}$, respectively. Note that the values here are similar with the conductivity of the ligand (4) itself, which is $4.87 \times 10^{-7} \mathrm{~S}$ $\mathrm{cm}^{-1}$ (Figure S10), showing that coordination does not have a positive effect on the increasing conductivities. Considering the small difference among Y1, Y2, and Y3, we believe that it is related to the structure of the metal complex itself. The designed molecular materials have very limited conjugated structures because the metal in the center breaks the whole molecule into two separate entities. Previous reports on pure organic molecules as $\mathrm{HTMs}^{34}$ have mentioned this effect, which emphasizes the importance of a large conjugated system. It realistic to assume that this also can be extended to metal complexes. On the other hand, it could also originate from the electron density distribution in the ground state. According to the Bässler model, ${ }^{35}$ the inherent dipolarity of a molecule has an adverse effect on the charge-carrier transport. In our systems, the HOMO electrons are localized on the ligands, which gives the ligands a negative charge and the central metal a positive charge. This charge separation causes a dipolarity in all of the metal complexes because the single electron pair in $\mathrm{N}$ in the triphenylamine unit could then easily transfer to $\mathrm{N}$ in the pyrrole ring, as shown in Figure 5.

Further, these materials were investigated as hole-transport materials in the perovskite solar cells. By decreasing the film thickness (lower to $50 \mathrm{~nm}$ ), we could compensate for the disadvantage of low bulk charge transport properties. All three materials offered PSCs with voltages higher than $1 \mathrm{~V}$, whereas a voltage of only $0.52 \mathrm{~V}$ could be obtained for solar cells without applied HTMs (Figure S11). However, the main problem of the new HTMs is still the low conductivity. As seen in Figure $6 \mathrm{a}, \mathrm{Y} 2$ and $\mathrm{Y} 3$ do not significantly improve the photocurrent, showing 11.01 and $12.62 \mathrm{~mA} \mathrm{~cm}^{-2}$, respectively. Thus, a poorer overall performance of 6.0 and $7.1 \%$ was obtained as compared to Spiro-OMeTAD (17.3\%). Surprisingly, the best efficiency was obtained from the devices based on Y1, which offer a current density of $16.57 \mathrm{~mA} \mathrm{~cm}^{-2}$, a voltage of $1.06 \mathrm{~V}$, and a fill factor of 0.63 to yield an efficiency of $11.1 \%$. The hysteresis phenomenon was also investigated and is shown in Figure 6 a. All Y1, Y2, and Y3 display a high hysteresis with lower fill factor, indicating that metal complex hole-transport materials have minor effect on reducing the hysteresis. Corresponding data are summarized in Table 4. Distribution of 20 devices based on $\mathrm{Y} 1, \mathrm{Y} 2$, and $\mathrm{Y} 3$ as hole-transport materials in the

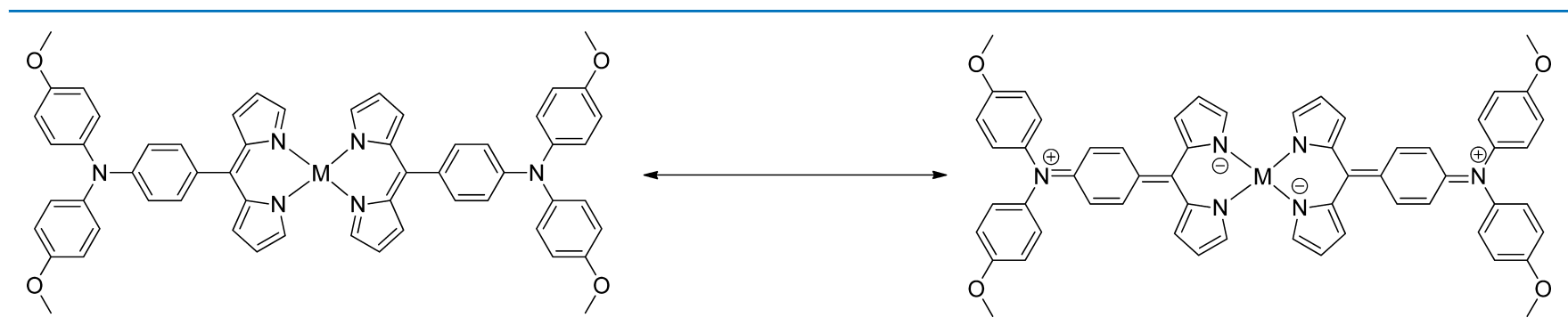

Figure 5. Resonance structures of the metal complexes in the ground state. 

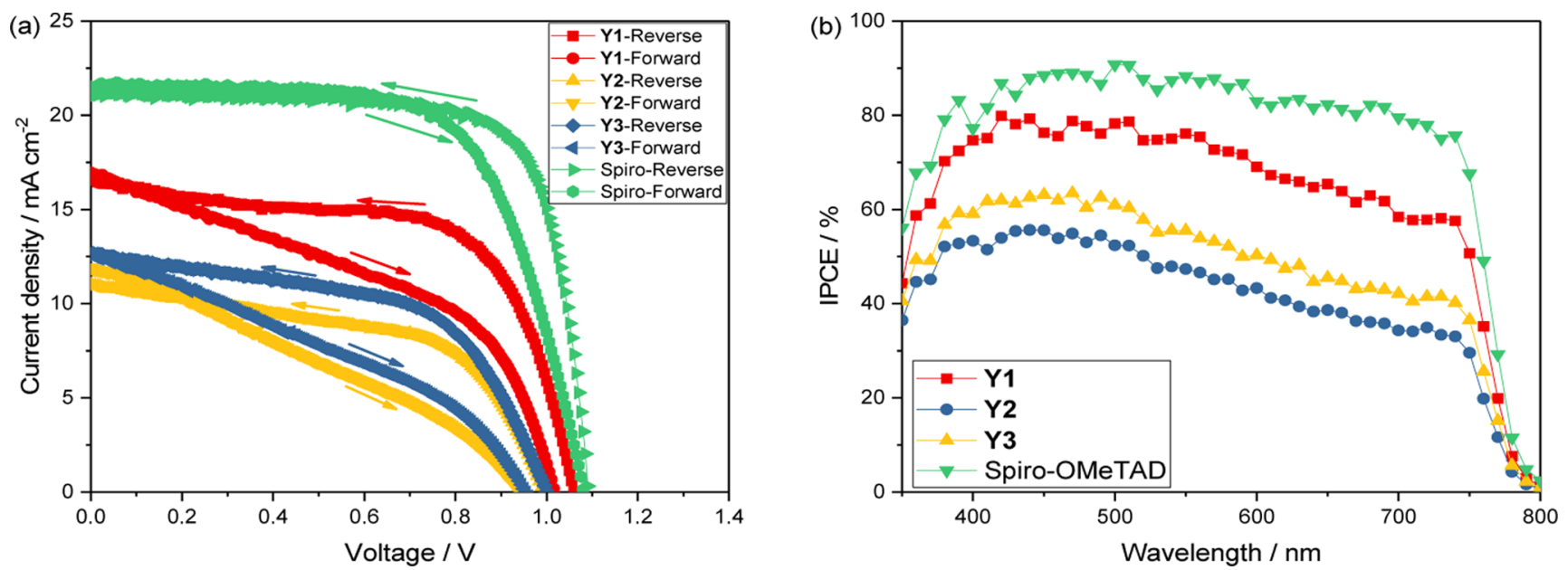

Figure 6. (a) $J-V$ curves for devices based on Y1, Y2, Y3, or Spiro-OMeTAD as the hole-transport material. (b) Incident photon-to-current conversion efficiency (IPCE) spectra for devices based on Y1, Y2, Y3, or Spiro-OMeTAD as the hole-transport materials.

Table 4. Photovoltaic Performance Including Hysteresis Phenomenon for PSCs Based on Y1, Y2, Y3, and SpiroOMeTAD, as Well as without Any Hole-Transport Material Applied

\begin{tabular}{lccccr}
\multicolumn{1}{c}{ HTMs } & scan direction & $J_{\mathrm{sc}} / \mathrm{mA} \mathrm{cm}^{-2}$ & $V_{\text {oc }} / \mathrm{V}$ & $\mathrm{FF}$ & $\eta / \%$ \\
$\mathrm{Y} 1$ & reverse & 16.57 & 1.06 & 0.63 & 11.1 \\
$\mathrm{Y} 1$ & forward & 16.97 & 1.02 & 0.45 & 7.7 \\
$\mathrm{Y} 2$ & reverse & 11.01 & 1.00 & 0.55 & 6.0 \\
$\mathrm{Y} 2$ & forward & 11.92 & 0.94 & 0.31 & 3.5 \\
$\mathrm{Y} 3$ & reverse & 12.62 & 1.00 & 0.56 & 7.1 \\
$\mathrm{Y} 3$ & forward & 12.59 & 0.96 & 0.34 & 4.1 \\
Spiro-OMeTAD & reverse & 21.13 & 1.09 & 0.75 & 17.3 \\
Spiro-OMeTAD & forward & 21.51 & 1.08 & 0.66 & 15.4 \\
without HTM & reverse & 13.70 & 0.52 & 0.42 & 3.0
\end{tabular}

perovskite solar cells are summarized in Figure S12, and a good reproducibility could be observed.

The incident photon-to-current conversion efficiency (IPCE) spectra of PSCs with Y1, Y2, Y3, or Spiro-OMeTAD as the hole-transport material are shown in Figure $6 \mathrm{~b}$. The results clearly show that devices with Y1 have the highest IPCE compared with Y2 and Y3, although it is still lower than that of Spiro-OMeTAD. This is in good agreement with the $J-V$ measurement, in which Y1 shows the highest current of 16.57 $\mathrm{mA} \mathrm{cm}{ }^{-2}$ among the three metal complexes. The integrated $J_{\mathrm{sc}}$ values from the IPCE spectra are 16.31, 10.65, 12.47, and 20.85 $\mathrm{mA} \mathrm{cm}{ }^{-2}$ for Y1, Y2, Y3, and Spiro-OMeTAD, respectively, matching the $J-V$ test results quite well.

On the basis of the photovoltaic performance shown in Table 4, all of the new materials work as hole scavengers and
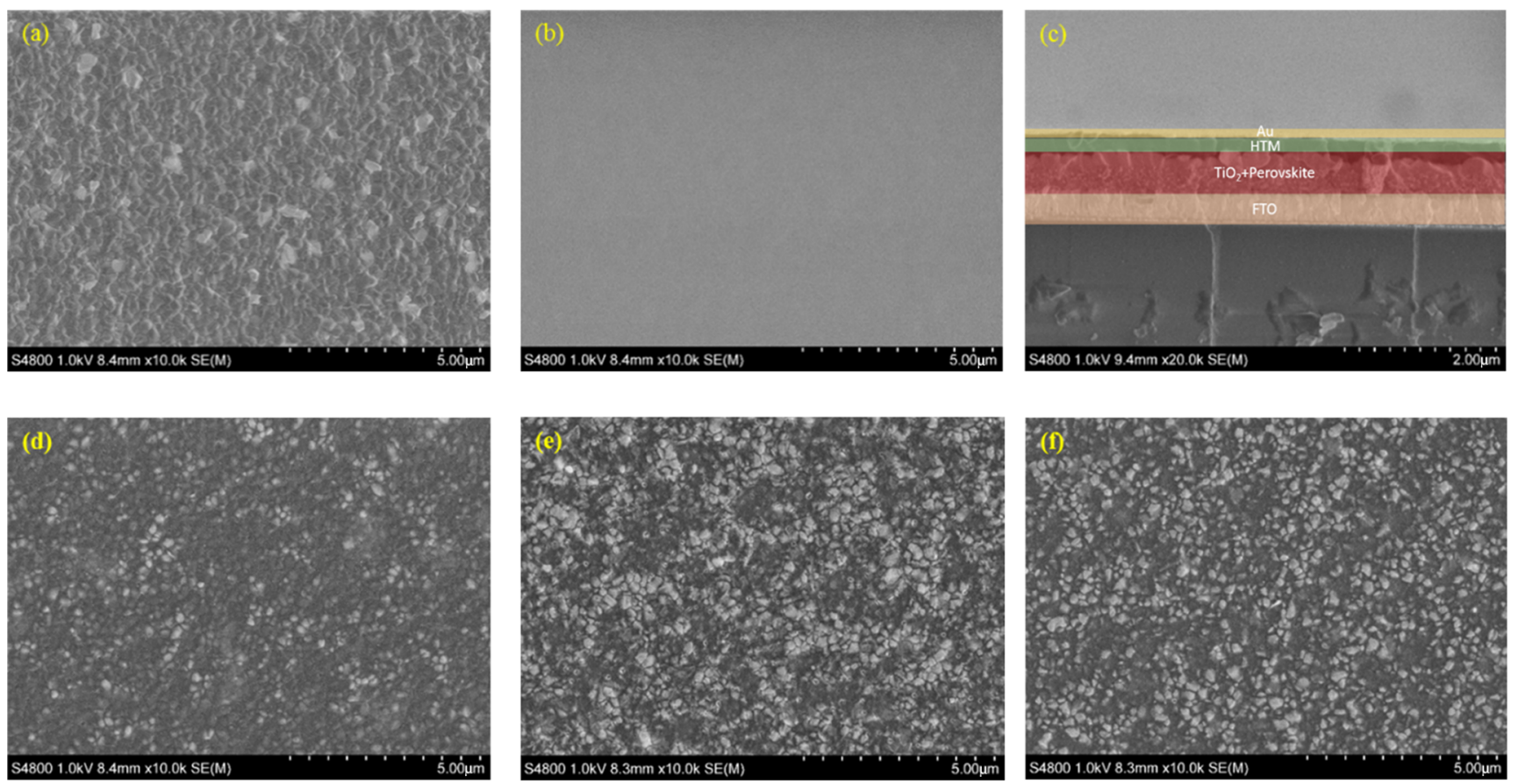

Figure 7. SEM images of (a) the surface of the naked perovskite material, (b) the surface after coating with Spiro-OMeTAD, (c) cross section of a perovskite solar cell when Spiro-OMeTAD is applied as the hole-transport material, (d) the surface after coating with Y1, (e) the surface after coating with $\mathrm{Y} 2$, and (f) the surface after coating with Y3. 

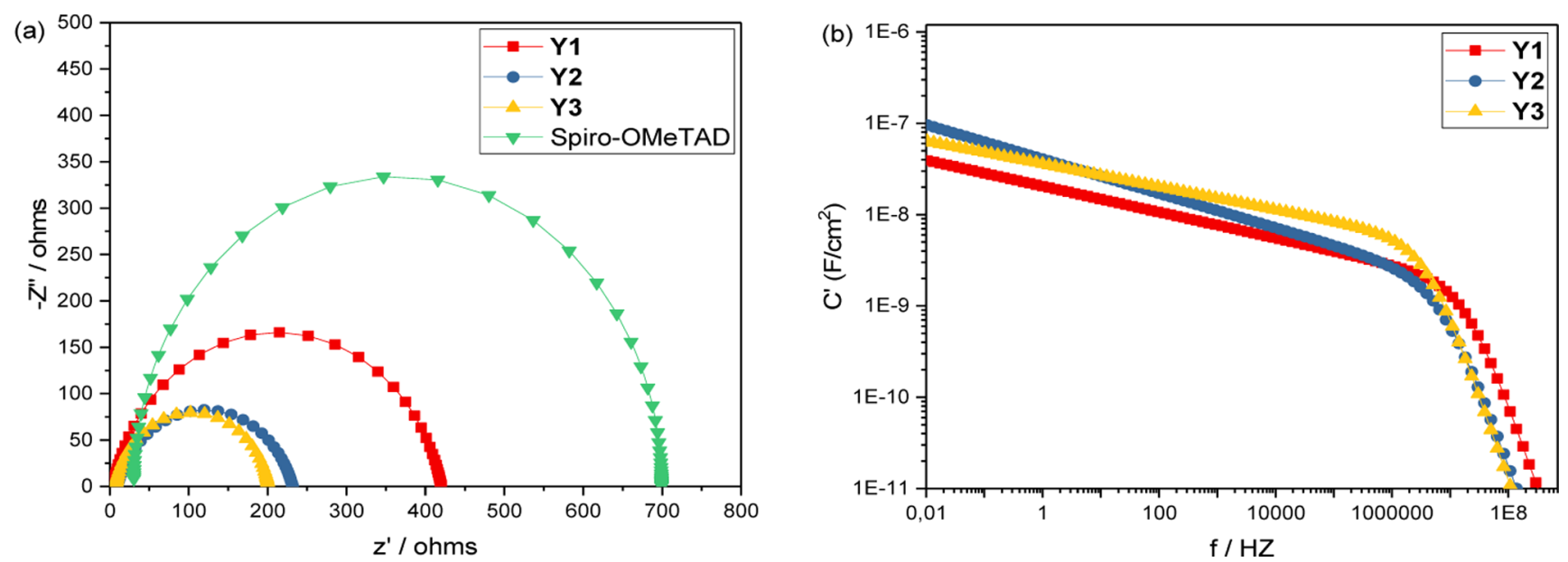

Figure 8. (a) EIS impedance of solar cells based on Y1, Y2, Y3, or Spiro-OMeTAD as HTMs, (b) capacitance of solar cells based on Y1, Y2, or Y3 as HTMs.

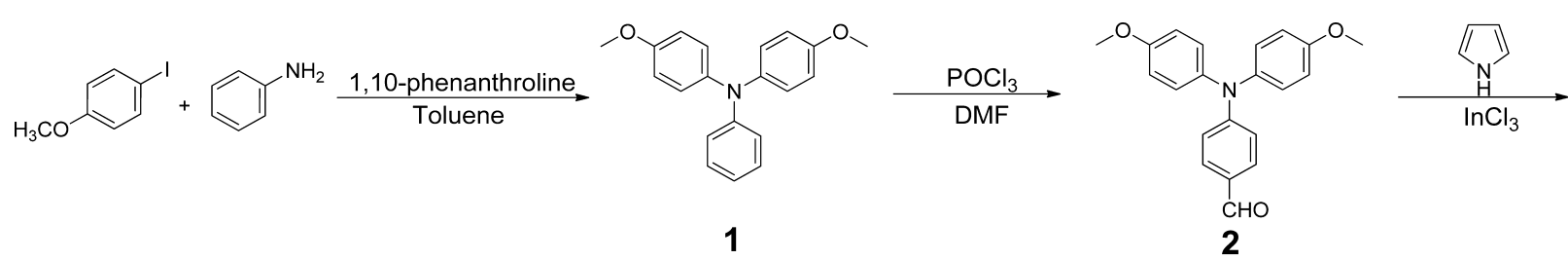

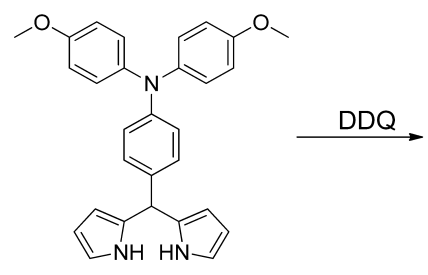

3

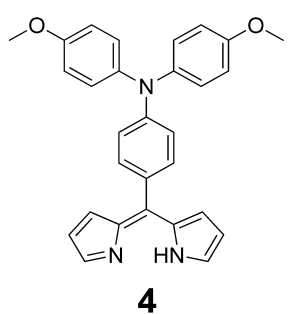

4

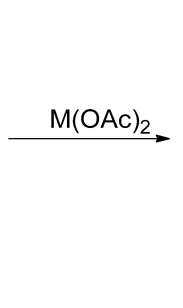

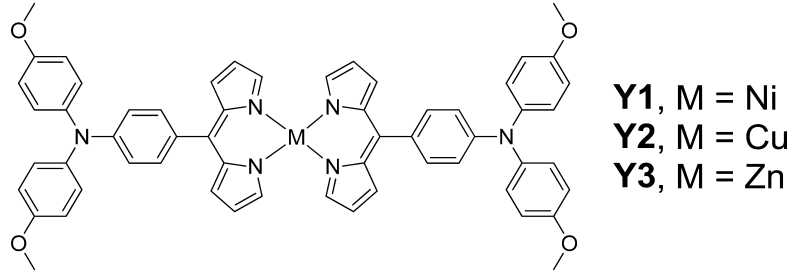

Y1, Y2, Y3

Figure 9. Synthetic route to render the metal complexes.

transport materials, but none is as good as Spiro-OMeTAD. The reason is mainly the low conductivities, as well as the low hole mobility, which hinder the charge-carrier transport. This limitation is also emphasized by an increase in the HTM layer thickness. Due to the low conductivity, an increase in layer thickness will result in a higher transport resistance, decreasing the current density and fill factor dramatically, as shown in Figure S13.

However, the film thickness can only be decreased to a certain thickness to compensate for this drawback. The scanning electron microscopy (SEM) images in Figure 7 show the film-forming properties of the different materials. Obviously, when using HTM concentration as low as $10 \mathrm{mg}$ $\mathrm{mL}^{-1}$, the perovskite surface does not become well covered. Further decrease in thickness will cause an increase in the recombination losses because of uncovered perovskite coming in contact with the gold counter electrode material. Comparing the covered perovskite films by the metal complex materials when the same HTM concentration of the spin-coating solution was used, Y1 forms a much better film than $\mathrm{Y} 2$ and $\mathrm{Y} 3$. Figure $7 \mathrm{e}, \mathrm{f}$ indicates that aggregation is a serious problem for the Y2 and Y3 systems. A large area with noncovered perovskite will allow direct contact with the gold counter electrode material, resulting in higher recombination losses and thus a smaller shunt resistance $\left(R_{\mathrm{sh}}\right)$ decreasing both the fill factor and the current as compared to Y1.

Furthermore, we investigated the impedance and capacitance using electrochemical impedance spectroscopy (EIS) of the solar cells based on Y1, Y2, Y3, or Spiro-OMeTAD as an HTM to study the interface properties. The results are shown in Figure 8. As expected, Y1 shows the lowest series resistance $\left(R_{\mathrm{s}}\right)$, which is about $4 \Omega$, lower than those of the devices based on Y2 and Y3, which are 9 and $7 \Omega$, respectively. The lower series resistance is linked to a high PSC photocurrent. In addition, we note that although PSCs based on metal complexes show a lower recombination resistance $\left(R_{\text {rec }}\right)$ than those with Spiro-OMeTAD, devices based on Y1 still show the highest $R_{\text {rec }}$ among the three complexes, in good agreement with the photovoltaic performance in Figure 6a. We believe that this is because of the better film-forming ability of Y1 on the perovskite surface, preventing shunts between the perovskite and counter electrode materials. This effect is also indicated by the capacitances shown in Figure 8b. Devices based on Y1 display the lowest capacitance at low frequencies, whereas devices based on Y2 and Y3 show lower capacitances in the high-frequency region $\left(>10^{5} \mathrm{~Hz}\right)$. This is because at low 
frequency a better film of Y1 could efficiently extract and transport the holes. Thus, a lower capacitance could be achieved compared with $\mathrm{Y} 2$ and $\mathrm{Y} 3$. However, in the highfrequency region, the perovskite-HTM interface for devices based on Y1 experience a higher charge accumulation due to faster and better extraction ability, but a low carrier-transport ability. The excess of holes on the interface may result in a higher capacitance.

\section{CONCLUSIONS}

In summary, we have successfully designed and synthesized three metal complexes with TPA derivative ligands coordinated to nickel, copper, and zinc. These materials show very similar HOMO energy levels but an increase in band gaps going from nickel to copper to zinc. Also, these materials show high holeextraction efficiencies but low hole mobilities and conductivities, resulting in satisfactory, but not excellent, PSC performance when applied as hole-transport materials. The best device performance was observed for the material based on nickel, with a conversion efficiency of $11.1 \%$. This can most likely be ascribed the better film-forming ability on the perovskite surface. Application as dopants for Spiro-OMeTAD was not successful in spite of the more negative HOMO energy levels (vs vacuum). The current results will act as a guideline when exploring metal complexes as the hole-transport materials.

\section{EXPERIMENTAL SECTION}

Materials. Chemicals and solvents were purchased from Sigma-Aldrich and used without further purification except when mentioned. Lead iodide $\left(\mathrm{PbI}_{2}, 99.99 \%\right)$ and lead bromide $\left(\mathrm{PbBr}_{2}, 99.99 \%\right)$ were purchased from TCI and Alfa Aesar, respectively. Formamidinium iodide (FAI, $\mathrm{CH}\left(\mathrm{NH}_{2}\right)_{2} \mathrm{I},>98 \%$ ) and methylammonium bromide $\left(\mathrm{MABr}, \mathrm{CH}_{3} \mathrm{NH}_{3} \mathrm{Br}\right.$, >98\%) were purchased from Dyenamo and were recrystallized before use. FK209 (Co(III) TFSI salt, 98\%) was also purchased from Dyenamo. $\mathrm{TiO}_{2}$ paste with an average particle diameter of 30 $\mathrm{nm}$ was purchased from Dyesol. Pyrrole was purchased from Sigma-Aldrich and distilled before use.

Synthetic Route. Synthetic route is shown in Figure 9.

4-Methoxy-N-(4-methoxyphenyl)-N-phenylaniline (1). 4Iodoanisole $(6.5 \mathrm{~g}, 27.5 \mathrm{mmol})$, aniline $(1 \mathrm{~mL}, 11 \mathrm{mM})$, and 1,10-phenanthroline $(0.4 \mathrm{~g}, 2.2 \mathrm{mmol})$ were dissolved in $25 \mathrm{~mL}$ toluene. The solution was protected by nitrogen and heated to $100{ }^{\circ} \mathrm{C}$ and $\mathrm{CuI}(0.42 \mathrm{~g}, 2.2 \mathrm{mmol})$ and powdered $\mathrm{KOH}(4.63$ g, $82.5 \mathrm{mmol}$ ) were added carefully. The solution was then kept at $100{ }^{\circ} \mathrm{C}$ overnight. When finished, the reaction was allowed to cool to room temperature. The organic phase was extracted with $\mathrm{DCM} / \mathrm{H}_{2} \mathrm{O}$ and dried with anhydrous $\mathrm{Na}_{2} \mathrm{SO}_{4}$. After removing the solvent, the residue was purified by silica gel column (petrol ether $(\mathrm{PE}) /$ ethyl acetate $(\mathrm{EA})=20 / 1)$, giving an orange solid (1.85 g, 55\% yield). ${ }^{1} \mathrm{H}$ NMR (400 MHz, $\left.\mathrm{CDCl}_{3}\right) \delta 7.17(\mathrm{t}, 2 \mathrm{H}), 7.04(\mathrm{~d}, 4 \mathrm{H}), 6.93(\mathrm{~d}, 2 \mathrm{H}), 6.84(\mathrm{~d}$, $1 \mathrm{H}), 6.81$ (d, $4 \mathrm{H}), 3.79$ (s, 6H).

4-(Bis(4-methoxyphenyl)amino)benzaldehyde (2). 1 (1.56 g, $4.68 \mathrm{mmol}$ ) was dissolved in $30 \mathrm{~mL}$ dimethylformamide (DMF). After cooling to $0{ }^{\circ} \mathrm{C}, \mathrm{POCl}_{3}(0.72 \mathrm{~mL}, 7.56 \mathrm{mmol})$ was added dropwise. The reaction was then performed at $90{ }^{\circ} \mathrm{C}$ for $3 \mathrm{~h}$. When finished, rotary evaporation was used to remove the solvent. The residual was dissolved in $\mathrm{H}_{2} \mathrm{O}$ and extracted with $\mathrm{CHCl}_{3}$, followed by drying with anhydrous $\mathrm{Na}_{2} \mathrm{SO}_{4}$. After removing the solvent, the residue was further purified by silica gel column $(\mathrm{PE} / \mathrm{EA}=1 / 1)$ to afford a yellow liquid (1.62 g,
95\% yield). ${ }^{1} \mathrm{H}$ NMR (400 MHz, $\mathrm{CDCl}_{3}$ ) $\delta 9.75$ (s, 1H), 7.61 (d, 2H), $7.12(\mathrm{~d}, 4 \mathrm{H}), 6.90(\mathrm{~d}, 4 \mathrm{H}), 6.88(\mathrm{~d}, 2 \mathrm{H}), 3.82(\mathrm{~s}, 6 \mathrm{H})$. 4-(Di(1H-pyrrol-2-yl)methyl)-N,N-bis(4-methoxyphenyl)aniline (3). 2 (1.6 g, $4.8 \mathrm{mmol})$ and freshly distilled pyrrole (30 $\mathrm{mL}, 0.44 \mathrm{~mol})$ were treated with $\mathrm{InCl}_{3}(0.2 \mathrm{~g}, 1.0 \mathrm{mmol})$ at room temperature under nitrogen. After stirring overnight, the solution was filtered to remove $\mathrm{InCl}_{3}$. Excess pyrrole was further removed by rotary evaporation under reduced pressure. The residue was eluted by silica gel column with $\mathrm{PE} / \mathrm{EA}=2 / 1$ to afford a light yellow solid ( $1.85 \mathrm{~g}, 86 \%$ yield). ${ }^{1} \mathrm{H}$ NMR (400 $\left.\mathrm{MHz}, \mathrm{CDCl}_{3}\right) \delta 7.94$ (d, 2H), 7.05 (d, 2H), 7.03 (d, 4H), 6.88 $(\mathrm{d}, 2 \mathrm{H}), 6.82(\mathrm{~d}, 4 \mathrm{H}), 6.69(\mathrm{~d}, 2 \mathrm{H}), 6.16(\mathrm{~d}, 2 \mathrm{H}), 5.94(\mathrm{~d}, 2 \mathrm{H})$, $5.38(\mathrm{~s}, 1 \mathrm{H}), 3.79(\mathrm{~s}, 6 \mathrm{H}) .{ }^{13} \mathrm{C} \mathrm{NMR}\left(100 \mathrm{MHz}, \mathrm{CDCl}_{3}\right) \delta$ $155.79,147.63,141.05,133.92,132.95,128.89,126.48,120.73$, 117.09, 114.70, 108.41, 107.04, 55.53, 43.32.

(Z)-4-((1H-pyrrol-2-yl)(2H-pyrrol-2-ylidene)methyl)- $\mathrm{N}, \mathrm{N}$ bis(4-methoxyphenyl)aniline (4). 3 (0.9 g, $2 \mathrm{mmol})$ was dissolved in $40 \mathrm{~mL}$ dry tetrahydrofuran (THF) and stirred at room temperature under nitrogen. 2,3-Dichloro-5,6-dicyano1,4-benzoquinone $(0.48 \mathrm{~g}, 2.1 \mathrm{mmol})$ was dissolved in $4 \mathrm{~mL}$ dry THF and added dropwise. The solution was then allowed to react at room temperature for $1 \mathrm{~h}$. When the reaction finished, the mixture was concentrated by rotary evaporation and eluted with $\mathrm{PE} / \mathrm{EA}=1 / 1$ in the first step and EA in the second step by silica gel column, giving a dark yellow solid (0.72 g, 80\% yield). ${ }^{1} \mathrm{H}$ NMR (400 MHz, dimethyl sulfoxide (DMSO)- $\left.d_{6}\right) \delta 7.92(\mathrm{~d}, 2 \mathrm{H}), 7.41(\mathrm{~d}, 2 \mathrm{H}), 7.28(\mathrm{~d}, 4 \mathrm{H}), 7.05$ (d, 4H), 6.98 (d, 2H), 6.82 (d, 2H), 6.69 (d, 2H), $3.79(\mathrm{~s}, 6 \mathrm{H})$. ${ }^{13} \mathrm{C}$ NMR (100 MHz, (DMSO)- $\left.d_{6}\right) \delta 158.24,154.58,151.20$, $139.61,138.05,137.80,132.98,131.25,130.87,129.00,117.31$, $116.29,115.93,55.91$.

$\mathrm{Ni}$-Di(4-((1H-pyrrol-2-yl) (2H-pyrrol-2-ylidene)methyl)- $\mathrm{N}, \mathrm{N}$ bis(4-methoxyphenyl)aniline) (Y1). 4 (134.3 mg, $0.3 \mathrm{mmol}$ ) and $\mathrm{Ni}(\mathrm{OAc})_{2} \cdot 4 \mathrm{H}_{2} \mathrm{O}(74.6 \mathrm{mg}, 0.3 \mathrm{mmol})$ were dissolved in 10 $\mathrm{mL} \mathrm{CH} \mathrm{CH}_{3} \mathrm{OH}$ and refluxed for $1 \mathrm{~h}$. When finished, cooling to room temperature and filtration were used to get the raw product. This raw product was further purified by recrystallization with $\mathrm{DCM} / \mathrm{MeOH}$, affording a dark red solid ( $88 \mathrm{mg}, 62 \%$ yield). ${ }^{1} \mathrm{H}$ NMR (400 MHz, acetone- $\left.d_{6}\right) \delta 10.94(\mathrm{~d}, 4 \mathrm{H}), 8.49$ (d, 4H), 7.79 (d, 4H), 7.29 (d, 4H), $7.19(\mathrm{~d}, 8 \mathrm{H}), 6.99$ (d, 8H), $6.88(\mathrm{~d}, 4 \mathrm{H}), 3.82(\mathrm{~s}, 12 \mathrm{H}) .{ }^{13} \mathrm{C}$ NMR $\left(100 \mathrm{MHz} \mathrm{CDCl}_{3}\right) \delta$ $156.51,151.94,149.43,140.43,139.66,128.51,127.65,125.39$, $117.77,115.58,55.77,34.87,30.92$, 21.54. High-resolution mass spectrometry (HRMS) (ESI) $m / z$ calcd for $\mathrm{C}_{58} \mathrm{H}_{48} \mathrm{~N}_{6} \mathrm{NiO}_{4}[\mathrm{M}$ $+\mathrm{H}]^{+}$951.31, found 951.32.

Cu-Di(4-((1H-pyrrol-2-yl)(2H-pyrrol-2-ylidene)methyl)- $\mathrm{N}, \mathrm{N}$ bis(4-methoxyphenyl)aniline) (Y2). 4 (134.3 mg, $0.3 \mathrm{mmol}$ ) and $\mathrm{Cu}(\mathrm{OAc})_{2} \cdot \mathrm{H}_{2} \mathrm{O}(40 \mathrm{mg}, 0.2 \mathrm{mmol})$ were dissolved in 10 $\mathrm{mL} \mathrm{CH} \mathrm{CH}_{3} \mathrm{OH}$ and refluxed for $1 \mathrm{~h}$. When the reaction finished, cooling to room temperature and filtrating were used to get the raw product. This product was further purified by silica gel column $(\mathrm{PE} / \mathrm{DCM}=1 / 1)$, followed by recrystallization with $\mathrm{DCM} / \mathrm{MeOH}$ again, affording a yellow solid (85 mg, 59\% yield). HRMS (ESI) $m / z$ calcd for $\mathrm{C}_{58} \mathrm{H}_{48} \mathrm{~N}_{6} \mathrm{CuO}_{4}[\mathrm{M}+\mathrm{H}]^{+}$ 956.30, found 956.31 .

Zn-Di(4-((1H-pyrrol-2-yl)(2H-pyrrol-2-ylidene)methyl)-N,Nbis(4-methoxyphenyl)aniline) (Y3). 4 (134.3 mg, $0.3 \mathrm{mmol}$ ) and $\mathrm{Zn}(\mathrm{OAc})_{2}(27.6 \mathrm{mg}, 0.15 \mathrm{mmol})$ were dissolved in $10 \mathrm{~mL}$ $\mathrm{CH}_{3} \mathrm{OH}$ and refluxed for $1 \mathrm{~h}$. When the reaction finished, cooling to room temperature and filtrating were used to get the raw product. This raw product was further purified by recrystallization with $\mathrm{DCM} / \mathrm{MeOH}$, affording a brown solid (128 mg, 89\% yield). ${ }^{1} \mathrm{H} \mathrm{NMR}\left(400 \mathrm{MHz}, \mathrm{CDCl}_{3}\right) \delta 7.49$ (d, 
$4 \mathrm{H}), 7.38$ (d, 4H), 7.18 (d, 8H), 6.96 (d, 4H), 6.90 (d, 4H), $6.88(\mathrm{~d}, 8 \mathrm{H}), 6.42(\mathrm{~d}, 4 \mathrm{H}), 3.82(\mathrm{~s}, 12 \mathrm{H}) .{ }^{13} \mathrm{C}$ NMR $(100$ $\mathrm{MHz} \mathrm{CDCl}_{3}$ ) $\delta 159.75,156.33,149.46,149.09,140.77,140.45$, 132.81, 132.17, 130.57, 127.24, 117.69, 116.65, 114.88, 55.54. HRMS (ESI) $m / z$ calcd for $\mathrm{C}_{58} \mathrm{H}_{48} \mathrm{~N}_{6} \mathrm{ZnO}_{4}[\mathrm{M}+\mathrm{H}]^{+}$957.30, found 957.10 .

DFT Calculations. To elucidate the electronic properties of Y1, Y2, and Y3, optimization and single-point energy calculations were performed using the B3LYP hybrid functional and 6-31G* basis sets for the $\mathrm{C}, \mathrm{H}, \mathrm{N}$, and $\mathrm{O}$ atoms, without any symmetry constraints. All of the reported calculations were carried out by means of Gaussian 09. The LAN L2DZ effective core potential basis sets were used for the $\mathrm{Cu}, \mathrm{Zn}$, and $\mathrm{Ni}$ atoms.

Hole Mobility Measurements. Hole mobilities were estimated according to literature. ${ }^{31,36}$ Briefly, a hole-conducting-only device with the structure of FTO/poly(3,4-ethylenedioxythiophene):polystyrene sulfonate (PEDOT:PSS)/ $\mathrm{HTM} / \mathrm{Au}$ was fabricated. The fluorine-doped tin oxide (FTO) coated glass substrates (Pilkington TEC15) were etched with $\mathrm{Zn}$ powder and $2 \mathrm{M} \mathrm{HCl}$ solution. The substrates were then washed with soap, acetone, and alcohol by sonication for $30 \mathrm{~min}$. The remaining organic residues were removed using a plasma cleaner (Harrick Plasma) for $30 \mathrm{~min}$. A $40 \mathrm{~nm}$ PEDOT:PSS layer was then spin-coated at $3000 \mathrm{rpm}$ on the substrate, followed by annealing at $120^{\circ} \mathrm{C}$ for $20 \mathrm{~min}$. A $10 \mathrm{mg}$ $\mathrm{mL}^{-1}$ HTM solution in chloroform was spin-coated on top of the annealed PEDOT:PSS layer, followed by evaporation of an $80 \mathrm{~nm}$ thick gold film as the counter electrode. The $J-V$ characteristics of the devices were recorded with a Keithley 2400 Semiconductor Characterization System.

Conductivity Measurements. Conductivities were determined according to previous reports. ${ }^{32,33}$ Glass substrates without a conductive layer were carefully washed with soap, acetone, and alcohol by sonication for $30 \mathrm{~min}$. A mesoporous $\mathrm{TiO}_{2}$ layer was deposited by spin-coating at $3000 \mathrm{rpm}$ for $30 \mathrm{~s}$ using a solution of $30 \mathrm{~nm} \mathrm{TiO}$ paste (Dyesol DSL 30NR-T) in absolute $\mathrm{EtOH}(\mathrm{w} / \mathrm{w}=1 / 3)$. After spin-coating, the substrate was immediately placed on a hotplate at $80{ }^{\circ} \mathrm{C}$ for $15 \mathrm{~min}$ and then transferred to an oven and sintered at $500{ }^{\circ} \mathrm{C}$ for $30 \mathrm{~min}$. A $10 \mathrm{mg} \mathrm{mL}^{-1}$ HTM solution in chloroform was subsequently spin-coated on the mesoporous $\mathrm{TiO}_{2}$ layer, followed by evaporation of an $80 \mathrm{~nm}$ gold film as the counter electrode. The $J-V$ characteristics were recorded in dark conditions with a Keithley 2400 Semiconductor Characterization System.

Fabrication of solar cells. FTO glass substrates (14 $\Omega$ $\mathrm{sq}^{-1}$, Pilkington TEC) were cut into $12.5 \mathrm{~cm} \times 3 \mathrm{~cm}$ pieces. These pieces were then etched with $\mathrm{Zn}$ powder/2 $\mathrm{M} \mathrm{HCl}$ solution in the middle. After etching, all of the residuals on the glass were removed and washed with soap, acetone, and alcohol by sonication for $30 \mathrm{~min}$. The clean glass substrates were stored without further treatment.

A compact $\mathrm{TiO}_{2}$ layer was made by using a spray pyrolysis with a $0.2 \mathrm{M}$ solution of titanium(IV) tetraisopropoxide and 2 $\mathrm{M}$ acetylacetone in isopropyl alcohol at $450{ }^{\circ} \mathrm{C}$. Cooling to room temperature, the $12.5 \mathrm{~cm} \times 3 \mathrm{~cm}$ glass substrates were further cut into $2.5 \mathrm{~cm} \times 1.5 \mathrm{~cm}$ pieces. A mesoporous $\mathrm{TiO}_{2}$ layer was made by spin-coating at $4500 \mathrm{rpm}$ for $30 \mathrm{~s}$ using a solution of $30 \mathrm{~nm} \mathrm{TiO}_{2}$ paste (Dyesol DSL 30NR-T) in absolute EtOH $(w / w=1 / 5.5)$. After spin-coating, the substrate was immediately placed on a hotplate at $80{ }^{\circ} \mathrm{C}$ for $15 \mathrm{~min}$ and then transferred to an oven and sintered at $500{ }^{\circ} \mathrm{C}$ for $30 \mathrm{~min}$.
A $(\mathrm{FA})_{0.85}(\mathrm{MA})_{0.15} \mathrm{~Pb}\left(\mathrm{I}_{3}\right)_{0.85}\left(\mathrm{Br}_{3}\right)_{0.15}$ perovskite film was made by spin-coating at $4500 \mathrm{rpm}$ for $30 \mathrm{~s}$ inside an argon glovebox with a precursor solution containing $1.1 \mathrm{M} \mathrm{PbI}_{2}, 1 \mathrm{M}$ FAI, $0.2 \mathrm{M} \mathrm{PbBr}_{2}$, and $0.2 \mathrm{M} \mathrm{MABr}$ in a mixed solvent (DMF/ $\mathrm{DMSO}=4 / 1)$. During spin-coating, $125 \mu \mathrm{L}$ chlorobenzene was sprayed onto the film after $15 \mathrm{~s}$. After finishing, the substrates were immediately placed on a hotplate at $100{ }^{\circ} \mathrm{C}$ for $30 \mathrm{~min}$.

Hole-transport materials were spin-coated at $4000 \mathrm{rpm}$ for 30 $\mathrm{s}$ using different precursor solutions. For Spiro-OMeTAD, the solution contained $70 \mathrm{mM}$ Spiro-OMeTAD, $20 \mathrm{mM}$ LiTFSI, $200 \mathrm{mM}$ 4-tert-butylpyridine (TBP), and $2 \mathrm{mM}$ FK209 in chlorobenzene. For materials Y1, Y2, and Y3, the concentration used were $10 \mathrm{mg} \mathrm{mL}^{-1}$, with $10 \mathrm{mM}$ LiTFSI, $100 \mathrm{mM}$ TBP, and $4 \%$ volume 1,1,2,2-tetrachloroethane $(\mathrm{TeCA})^{37}$ as dopant (Figure S8). All of the solutions were prepared inside an argonfilled glovebox but spin-coated outside the glovebox.

The final step to fabricate a perovskite solar cell was the evaporation of a gold film as the counter electrode. A layer of $80 \mathrm{~nm} \mathrm{Au}$ was deposited sequentially under high vacuum $(<5 \times$ $10^{-5} \mathrm{~Pa}$ ) by thermal evaporation (Edwards Auto 306) through a shadow mask to form an active area of around $20 \mathrm{~mm}^{2}$.

Characterization. NMR spectra were recorded on a Bruker AVANCE $400 \mathrm{MHz}$ spectrometer. High-resolution mass spectra were collected with a Fourier transform-ion cyclotron resonance mass spectrometer instrument (Varian 7.0TFTICR$\mathrm{MS})$. Cyclic voltammetry (CV) was performed in dichloromethane with $0.1 \mathrm{M}(\mathrm{TBA}) \mathrm{PF}_{6}$ as the supporting electrolyte, a $\mathrm{Ag} / \mathrm{AgNO}_{3}$ electrode as the reference, a carbon-glass electrode as the working electrode, a $\mathrm{Pt}$ electrode as the counter electrode, and ferrocene/ferrocenium $\left(\mathrm{Fc} / \mathrm{Fc}^{+}\right)$as the internal reference using a $\mathrm{CH}$ Instruments electrochemical workstation (model $660 \mathrm{~A}$ ). The UV-vis absorption spectra were recorded on a Lambda 750 spectrophotometer using a $1 \mathrm{~cm}$ cuvette. The concentration of the initial solution used was $10^{-5} \mathrm{M}$. The steady-state photoluminescence (PL) was investigated using a CARY Eclipse fluorescence spectrophotometer with an excitation wavelength of $530 \mathrm{~nm}$. The scanning electron microscopy (SEM) images were recorded on a FEI-XL 30 series microscope. Film thickness was determined using a profilometer of model Veeco Dektak 150. The light source for the photocurrent-voltage $(J-V)$ measurements was an AM 1.5G solar simulator (Newport 91160-1000). The incident light intensity was $100 \mathrm{~mW} \mathrm{~cm} \mathrm{~cm}^{-2}$ calibrated using a certified Siphotodiode (Fraunhofer ISE). The size of the working electrode was $25 \times 3 \mathrm{~mm}^{2}$ on a substrate shared by four solar cells, and the counter electrode was $10 \times 4 \mathrm{~mm}^{2}$. The solar cells investigated were masked to a working area of 0.126 $\mathrm{cm}^{2}$. The photocurrent-voltage $(J-V)$ curves were obtained by the linear sweep voltammetry method using a Keithley 2400 source-measure unit with a scan rate $10 \mathrm{mV} \mathrm{s}^{-1}$. IPCE spectra were recorded on a computer-controlled setup with a light source ASB-XE-175, a monochromator (Spectral Products CM110), and a Keithley multimeter (model 2700). The setup was calibrated with a certified silicon solar cell (Fraunhofer ISE). Electrochemical impedance spectroscopy (EIS) and capacitance measurements were carried out using an Autolab PGstat12 potentiostat with an impedance module under a single sine function in dark with an applied bias potential of -1 $\mathrm{V}$. The frequency range used was $0.1-100000 \mathrm{~Hz}$, together with an oscillating amplitude of $10 \mathrm{mV}$. 


\section{ASSOCIATED CONTENT}

\section{S Supporting Information}

The Supporting Information is available free of charge on the ACS Publications website at DOI: 10.1021/acsomega.7b01434.

${ }^{1} \mathrm{H}$ NMR and ${ }^{13} \mathrm{C}$ NMR of $\mathrm{Y} 1$ and $\mathrm{Y} 3$; mass spectra of $\mathrm{Y} 1, \mathrm{Y} 2$, and $\mathrm{Y} 3$; UV-vis spectra of $\mathrm{Y} 3$ with gradual addition of different amounts of TeCA as dopant; UVvis absorption of Spiro-OMeTAD with gradual addition of different amounts of Y1, Y2, and Y3 as dopants; current-voltage characteristics of ligand (4) with doping; photovoltaic performance of perovskite solar cells without the hole-transport material; distribution of efficiencies of PSCs based on Y1, Y2, and Y3 as the hole-transport materials; photovoltaic performance with increased concentrations of Y1, Y2, and Y3 (Figures S1S13) (PDF)

\section{AUTHOR INFORMATION}

\section{Corresponding Authors}

*E-mail: yonghua@kth.se (Y.H.). *E-mail: larsa@kth.se (L.K.).

\section{ORCID}

Lars Kloo: 0000-0002-0168-2942

\section{Present Addresses}

${ }^{\#}$ School of Materials Science and Engineering, Yunnan University, Kunming 650000, P. R. China (Y.H.).

${ }^{\perp}$ Department of Chemistry, Applied Physical Chemistry, KTH Royal Institute of Technology, SE-10044 Stockholm, Sweden (Y.H.).

\section{Author Contributions}

The manuscript was written through contributions of all of the authors. All of the authors have given approval to the final version of the manuscript.

\section{Notes}

The authors declare no competing financial interest.

\section{ACKNOWLEDGMENTS}

This work was financially supported by the Swedish Energy Agency, the Swedish Research Council, the Knut and Alice Wallenberg Foundation. The author Wei Zhang thanks the China Scholarship Council (CSC) for the financial support.

\section{REFERENCES}

(1) Kang, R.; Yeo, J.-S.; Lee, H. J.; Lee, S.; Kang, M.; Myoung, N.; Yim, S.-Y.; Oh, S.-H.; Kim, D.-Y. Exploration of fabrication methods for planar $\mathrm{CH}_{3} \mathrm{NH}_{3} \mathrm{PbI}_{3}$ perovskite solar cells. Nano Energy 2016, 27, $175-184$.

(2) Yang, W. S.; Park, B.-W.; Jung, E. H.; Jeon, N. J.; Kim, Y. C.; Lee, D. U.; Shin, S. S.; Seo, J.; Kim, E. K.; Noh, J. H.; Seok, S. I. Iodide management in formamidinium-lead-halide-based perovskite layers for efficient solar cells. Science 2017, 356, 1376-1379.

(3) Chen, W.; Wu, Y.; Yue, Y.; Liu, J.; Zhang, W.; Yang, X.; Chen, H.; Bi, E.; Ashraful, I.; Gratzel, M.; Han, L. Efficient and stable large-area perovskite solar cells with inorganic charge extraction layers. Science 2015, 350, 944-948.

(4) Rehman, W.; Milot, R. L.; Eperon, G. E.; Wehrenfennig, C.; Boland, J. L.; Snaith, H. J.; Johnston, M. B.; Herz, L. M. ChargeCarrier Dynamics and Mobilities in Formamidinium Lead MixedHalide Perovskites. Adv. Mater. 2015, 27, 7938-7944.

(5) Stranks, S. D.; Eperon, G. E.; Grancini, G.; Menelaou, C.; Alcocer, M. J. P.; Leijtens, T.; Herz, L. M.; Petrozza, A.; Snaith, H. J. Electron-Hole Diffusion Lengths Exceeding 1 Micrometer in an
Organometal Trihalide Perovskite Absorber. Science 2013, 342, 341344.

(6) Lin, Q.; Armin, A.; Nagiri, R. C. R.; Burn, P. L.; Meredith, P. Electro-optics of perovskite solar cells. Nat. Photonics 2014, 9, 106112.

(7) Noel, N. K.; Stranks, S. D.; Abate, A.; Wehrenfennig, C.; Guarnera, S.; Haghighirad, A.-A.; Sadhanala, A.; Eperon, G. E.; Pathak, S. K.; Johnston, M. B.; Petrozza, A.; Herz, L. M.; Snaith, H. J. Lead-free organic-inorganic tin halide perovskites for photovoltaic applications. Energy Environ. Sci. 2014, 7, 3061.

(8) Kumar, M. H.; Dharani, S.; Leong, W. L.; Boix, P. P.; Prabhakar, R. R.; Baikie, T.; Shi, C.; Ding, H.; Ramesh, R.; Asta, M.; Graetzel, M.; Mhaisalkar, S. G.; Mathews, N. Lead-free halide perovskite solar cells with high photocurrents realized through vacancy modulation. Adv. Mater. 2014, 26, 7122-7127.

(9) Park, B.-W.; Philippe, B.; Zhang, X.; Rensmo, H.; Boschloo, G.; Johansson, E. M. J. Bismuth Based Hybrid Perovskites A3Bi2 I9 (A: Methylammonium or Cesium) for Solar Cell Application. Adv. Mater. 2015, 27, 6806-6813.

(10) Jacobsson, T. J.; Correa-Baena, J.-P.; Pazoki, M.; Saliba, M.; Schenk, K.; Grätzel, M.; Hagfeldt, A. Exploration of the compositional space for mixed lead halogen perovskites for high efficiency solar cells. Energy Environ. Sci. 2016, 9, 1706-1724.

(11) Bi, D.; Yi, C.; Luo, J.; Décoppet, J.-D.; Zhang, F.; Zakeeruddin, S. M.; Li, X.; Hagfeldt, A.; Grätzel, M. Polymer-templated nucleation and crystal growth of perovskite films for solar cells with efficiency greater than 21\%. Nat. Energy 2016, 1, No. 16142.

(12) Wang, F.; Geng, W.; Zhou, Y.; Fang, H.-H.; Tong, C.-J.; Loi, M. A.; Liu, L.-M.; Zhao, N. Phenylalkylamine Passivation of Organolead Halide Perovskites Enabling High-Efficiency and Air-Stable Photovoltaic Cells. Adv. Mater. 2016, 28, 9986-9992.

(13) Yang, S.; Wang, Y.; Liu, P.; Cheng, Y.-B.; Zhao, H. J.; Yang, H. G. Functionalization of perovskite thin films with moisture-tolerant molecules. Nat. Energy 2016, 1, No. 15016.

(14) Wen, X.; Wu, J.; Ye, M.; Gao, D.; Lin, C. Interface engineering via an insulating polymer for highly efficient and environmentally stable perovskite solar cells. Chem. Commun. 2016, 52, 11355-11358.

(15) Bella, F.; Griffini, G.; Correa-Baena, J.-P.; Saracco, G.; Grätzel, M.; Hagfeldt, A.; Turri, S.; Gerbaldi, C. Improving efficiency and stability of perovskite solar cells with photocurable fluoropolymers. Science 2016, 354, 203-206.

(16) Xu, B.; Bi, D.; Hua, Y.; Liu, P.; Cheng, M.; Grätzel, M.; Kloo, L.; Hagfeldt, A.; Sun, L. A low-cost spiro[fluorene-9,9'-xanthene]-based hole transport material for highly efficient solid-state dye-sensitized solar cells and perovskite solar cells. Energy Environ. Sci. 2016, 9, 873877.

(17) Nazeeruddin, M. K.; Kay, A.; Rodicio, I.; Humpbry-Baker, R.; Miiller, E.; Liska, P.; Vlachopoulos, N.; Graetzel, M. Conversion of Light to Electricity by cis- $\mathrm{X}_{2} \operatorname{Bis}\left(2,2^{\prime}\right.$-bipyridyl-4,4' dicarboxylate)ruthenium(II) Charge-Transfer Sensitizers $\left(\mathrm{X}=\mathrm{Cl}^{-}, \mathrm{Br}^{-}, \mathrm{I}^{-}, \mathrm{CN}^{-}\right.$, and $\mathrm{SCN}^{-}$) on Nanocrystalline $\mathrm{TiO}_{2}$ Electrodes. J. Am. Chem. Soc. 1993, 115, 6382-6390.

(18) Nazeeruddin, M. K.; Humphry-Baker, R.; Liska, P.; Grätzel, M. Investigation of Sensitizer Adsorption and the Influence of Protons on Current and Voltage of a Dye-Sensitized Nanocrystalline $\mathrm{TiO}_{2}$ Solar Cell. J. Phys. Chem. B 2003, 107, 8981-8987.

(19) Nazeeruddin, M. K.; Péchy, P.; Renouard, T.; Zakeeruddin, S. M.; Humphry-Baker, R; Comte, P.; Liska, P.; Cevey, L.; Costa, E.; Shklover, V.; Spiccia, L.; Deacon, G. B.; Bignozzi, C. A.; Grätzel, M. Engineering of Efficient Panchromatic Sensitizers for Nanocrystalline $\mathrm{TiO}_{2}$-Based Solar Cells. J. Am. Chem. Soc. 2001, 123, 1613-1624.

(20) Yum, J.-H.; Baranoff, E.; Kessler, F.; Moehl, T.; Ahmad, S.; Bessho, T.; Marchioro, A.; Ghadiri, E.; Moser, J.-E.; Yi, C.; Nazeeruddin, M. K.; Grätzel, M. A cobalt complex redox shuttle for dye-sensitized solar cells with high open-circuit potentials. Nat. Commun. 2012, 3, No. 631.

(21) Cong, J.; Kinschel, D.; Daniel, Q.; Safdari, M.; Gabrielsson, E.; Chen, H.; Svensson, P. H.; Sun, L.; Kloo, L. Bis(1,1-bis(2- 
pyridyl)ethane)copper(I/II) as an efficient redox couple for liquid dyesensitized solar cells. J. Mater. Chem. A 2016, 4, 14550.

(22) Hua, Y.; Xu, B.; Liu, P.; Chen, H.; Tian, H.; Cheng, M.; Kloo, L.; Sun, L. High conductivity Ag-based metal organic complexes as dopant-free hole-transport materials for perovskite solar cells with high fill factors. Chem. Sci. 2016, 7, 2633-2638.

(23) Chou, H.-H.; Chiang, Y.-H.; Li, M.-H.; Shen, P.-S.; Wei, H.-J.; Mai, C.-L.; Chen, P.; Yeh, C.-Y. Zinc Porphyrin-Ethynylaniline Conjugates as Novel Hole-Transporting Materials for Perovskite Solar Cells with Power Conversion Efficiency of 16.6\%. ACS Energy Lett. 2016, 1, 956-962.

(24) Burschka, J.; Kessler, F.; Nazeeruddin, M. K.; Grätzel, M. Co(III) Complexes as p-Dopants in Solid-State Dye-Sensitized Solar Cells. Chem. Mater. 2013, 25, 2986.

(25) Chen, C.; Zhang, W.; Cong, J.; Cheng, M.; Zhang, B.; Chen, H.; Liu, P.; Li, R.; Safdari, M.; Kloo, L.; Sun, L. Cu(II) Complexes as pType Dopants in Efficient Perovskite Solar Cells. ACS Energy Lett. 2017, 2, 497-503.

(26) Freitag, M.; Daniel, Q.; Pazoki, M.; Sveinbjörnsson, K.; Zhang, J.; Sun, L.; Hagfeldt, A.; Boschloo, G. High-efficiency dye-sensitized solar cells with molecular copper phenanthroline as solid hole conductor. Energy Environ. Sci. 2015, 8, 2634-2637.

(27) Das, S.; Gupta, I. Triphenylamine substituted dipyrrinato metal complexes: Synthesis, optical and electrochemical studies. Inorg. Chem. Commun. 2015, 60, 54-60.

(28) Yu, L.; Muthukumaran, K.; Sazanovich, I. V.; Kirmaier, C.; Hindin, E.; Diers, J. R.; Boyle, P. D.; Bocian, D. F.; Holten, D.; Lindsey, J. S. Excited-State Energy-Transfer Dynamics in SelfAssembled Triads Composed of Two Porphyrins and an Intervening Bis(dipyrrinato)metal Complex. Inorg. Chem. 2003, 42, 6629-6647.

(29) Xu, B.; Tian, H.; Bi, D.; Gabrielsson, E.; Johansson, E. M. J.; Boschloo, G.; Hagfeldt, A.; Sun, L. Efficient solid state dye-sensitized solar cells based on an oligomer hole transport material and an organic dye. J. Mater. Chem. A 2013, 1, 14467.

(30) Khalil, M. M. H.; Ismail, E. H.; Mohamed, G. G.; Zayed, E. M.; Badr, A. Synthesis and characterization of a novel Schiff base metal complexes and their application in determination of iron in different types of natural water. Open J. Inorg. Chem. 2012, 02, 13-21.

(31) Goh, C.; Kline, R. J.; McGehee, M. D.; Kadnikova, E. N.; Fréchet, J. M. J. Molecular-weight-dependent mobilities in regioregular poly(3-hexyl-thiophene) diodes. Appl. Phys. Lett. 2005, 86, No. 122110.

(32) Snaith, H. J.; Grätzel, M. Enhanced charge mobility in a molecular hole transporter via addition of redox inactive ionic dopant: Implication to dye-sensitized solar cells. Appl. Phys. Lett. 2006, 89, No. 262114.

(33) Snaith, H. J.; Grätzel, M. Electron and Hole Transport through Mesoporous $\mathrm{TiO}_{2}$ Infiltrated with Spiro-MeOTAD. Adv. Mater. 2007, 19, 3643-3647.

(34) Xu, B.; Tian, H.; Lin, L.; Qian, D.; Chen, H.; Zhang, J.; Vlachopoulos, N.; Boschloo, G.; Luo, Y.; Zhang, F.; Hagfeldt, A.; Sun, L. Integrated Design of Organic Hole Transport Materials for Efficient Solid-State Dye-Sensitized Solar Cells. Adv. Energy Mater. 2015, 5, No. 1401185.

(35) Hertel, D.; Bässler, H. Photoconduction in amorphous organic solids. ChemPhysChem 2008, 9, 666-688.

(36) Leijtens, T.; Ding, I.-K.; Giovenzana, T.; Bloking, J. T.; McGehee, M. D.; Sellinger, A. Hole Transport Materials with Low Glass Transition Temperatures and High Solubility for Application in Solid-State Dye-Sensitized Solar Cells. ACS Nano 2012, 6, 14551462.

(37) Xu, B.; Gabrielsson, E.; Safdari, M.; Cheng, M.; Hua, Y.; Tian, H.; Gardner, J. M.; Kloo, L.; Sun, L. 1,1,2,2-Tetrachloroethane (TeCA) as a Solvent Additive for Organic Hole Transport Materials and Its Application in Highly Efficient Solid-State Dye-Sensitized Solar Cells. Adv. Energy Mater. 2015, 5, No. 1402340. 